\title{
Platinum-group elements in the Pyroxenite Marker, Bushveld Complex: implications for the formation of the Main Zone
}

\author{
W.D. Maier \\ Centre for Research on Magmatic Ore Deposits, Department of Geology, \\ University of Pretoria, Pretoria 0002, South Africa \\ e-mail:wdmaier@scientia.up.ac.za \\ Sarah-Jane Barnes \\ Sciences de la Terre, Université du Québec à Chicoutimi, G7H2B1, Canada \\ sjbarnes@uqac.uquebec.ca \\ M. J. van der Merwe \\ PO Box 39636, Pretoria 0043, South Africa
}

\begin{abstract}
Concentrations of platinum-group elements and sulphides in the Pyroxenite Marker of the upper Main Zone are variable, but generally low (up to $100 \mathrm{ppb}$ PGE and 0.2 weight $\% \mathrm{~S}$ ). The metal patterns may mostly be explained by sulphide segregation from PGE depleted residual Upper Critical Zone magma, but they are inconsistent with sulphide segregation from a replenishing influx of undepleted Critical Zone magma. Instead, we favour a model whereby a relatively cool and dense Main Zone crystal mush intruded the Bushveld chamber during the later stages of the deposition of the Upper Critical Zone and displaced warmer and lighter residual magma depleted in chalcophile metals (Sharpe, 1985). Based on the metal contents and textural evidence such as the occurrence of ophitic textures, we hypothesize that the Pyroxenite Marker formed in response to localized supercooling and the suppression of plagioclase crystallization. The model implies that the layer represents a poor target for PGE mineralization in the upper portions of the Bushveld Complex.
\end{abstract}

\section{Introduction}

The Pyroxenite Marker is a prominent ultramafic layer located within the predominantly mafic Main Zone of the Bushveld Complex. It is commonly interpreted as a major replenishment to a relatively evolved Bushveld chamber with less differentiated magma (von Gruenewaldt, 1973; Molyneux, 1974; Mitchell, 1990; Kruger, 1994). Based on a laterally continuous PGE anomaly in a regional soil and stream sampling survey (Wilhelm et al., 1997), there has been some speculation about the presence of a PGE-enriched layer in the upper Main Zone particularly in view of the recent discovery of a PGE- and Au-rich horizon in the upper portion of the Skaergaard (Andersen et al., 1998) and Rincon del Tigre (Prendergast, 2000) intrusions. Visible sulphides in some samples from the Pyroxenite Marker suggest that the latter may be a potential target for such a PGE-enriched horizon. However, as yet no PGE data on the Pyroxenite Marker has been published apart from one analysis of a PGE-poor noritic sample reported by Harney et al. (1990).

Here, we provide noble metal data from 8 samples of the Pyroxenite Marker and 5 samples of its host rocks at 6 different localities in the western, eastern, and northern lobes of the Bushveld Complex (Figure1), to evaluate the economic potential of the layer, and to reassess existing models on its origin. Further, we briefly discuss some implications on the emplacement and crystallization of the Main Zone of the Bushveld Complex.

\section{Previous work}

The layered suite of the Bushveld Complex is generally sub-divided into 5 distinct stratigraphic intervals, the Marginal, Lower, Critical, Main, and Upper Zones. The Marginal Zone is largely noritic in character and may represent composite sills or rapidly cooled derivatives of the parental magmas to the Complex (Eales and Cawthorn, 1996). The Lower Zone and the lower portions of the Critical Zone consist of ultramafic rocks (mainly harzburgites and orthopyroxenites containing massive chromitite layers), which become increasingly diluted by norite and anorthosite towards the top of the Critical Zone. The Main Zone is a 3000-3300m package of noritic and gabbronoritic rocks, with lesser anorthosites (von Gruenewaldt, 1973; Molyneux, 1974; Mitchell, 1990). It is commonly subdivided into subzones A-C (von Gruenewaldt, 1973), based on the composition of the Ca-poor pyroxenes. The basal $1200 \mathrm{~m}$ subzone A consists of norite, anorthosite and gabbronorite, and the Ca-poor pyroxene is orthopyroxene. Subzone B is $1000 \mathrm{~m}$ thick and consists of lithologically and compositionally relatively homogenous gabbronorite, with pigeonite (now inverted to orthopyroxene) joining primary orthopyroxene as the Ca-poor pyroxene. The base of the 700$800 \mathrm{~m}$ thick noritic to gabbronoritic subzone $\mathrm{C}$ is, in many parts of the Bushveld Complex, defined by the 0.4-6m Pyroxenite Marker, where primary orthopyroxene may appear again as the sole Ca-poor pyroxene (Marais, 1977; Cawthorn et al., 1991). 


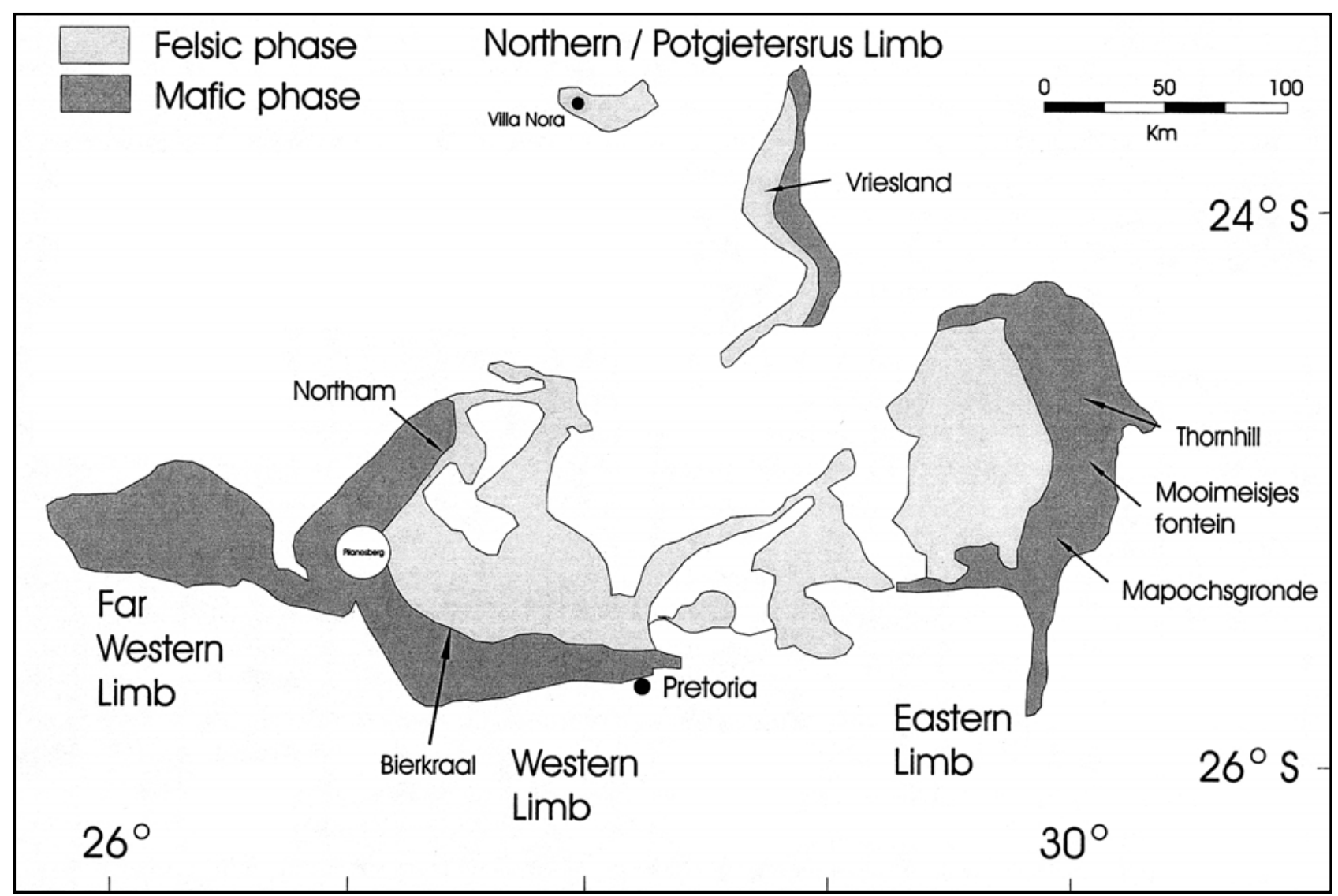

Figure 1. Simplified geological map, indicating sampling localities

However, there appears to be considerable regional variation in the nature of the Pyroxenite Marker. At some localities in the eastern and northern lobes of the Complex, there may be 2 orthopyroxenite layers developed (e.g. at Vriesland, Figure 1), at other localities the layer is a mela-gabbronorite, and yet elsewhere (e.g. at Northam mine) the Pyroxenite Marker is a clinopyroxenite. In the Villa Nora and Bon Accord areas the layer does not appear to be developed at all (Gold Fields in-house reports).

The mineralogical change occuring at the level of the Pyroxenite Marker is commonly accompanied by a compositional reversal, such as in $\mathrm{Mg \#}$ and $\mathrm{Cr}$ content of orthopyroxenes (Table 1) and in initial $\mathrm{Sr}$ isotopic ratio (Kruger et al., 1987; Cawthorn et al., 1991), towards values more typical of the upper Critical Zone. Notably, in several profiles, the reversal in differentiation index appears to occur over an interval several 100 metres in thickness bracketing the Pyroxenite Marker (von Gruenewaldt, 1973; Cawthorn et al., 1991).

\section{Field relationships}

Outcrop of the Pyroxenite Marker is generally relatively poor, except on the farm Mooimeisjesfontein, where the layer is well exposed in a cliff bordering the Mosohlotse stream (Figure 2). This exposure is remarkable because there are structures developed that we interpret to be the result of gravitational instability between relatively light basal anorthosite and overlying denser melanorite (load structures). The contact between the pyroxenite and the anorthosite forms a lobate surface with apices of the cusps reaching some $10 \mathrm{~cm}$ in height and spaced at intervals of $c a$. 1 to 3 metres. Flame-like anorthosite veins of up to $10 \mathrm{~cm}$ in width extend from the cusps into the overlying pyroxenite and gabbro, without deforming the layering in the mafic rock. This suggests upward percolation of an anorthositic magma or crystal mush in response to compaction. Lobate contacts between basal felsic and overlying mafic-ultramafic layers are also observed in the Upper Critical Zone, below the Merensky Reef, where they are either interpreted as erosional features (Lee, 1981; Eales et al., 1988) or

Table 1. Composition of orthopyroxene in the Pyroxenite Marker and its host rocks (data compiled from Marais, 1977)

\begin{tabular}{lcccr}
\hline & Thornhill & Steelpoortpark & Roossenekal & Tonteldoos \\
\hline Mg\#(opx) & & & & \\
above PM & 0.7 & 0.7 & 0.7 & 0.65 \\
PM & 0.74 & 0.74 & 0.74 & 0.62 \\
below PM & 0.66 & 0.65 & 0.69 & 0.56 \\
& & & & \\
Cr (opx, in ppm) & & & & \\
above PM & 506 & 775 & 400 & 300 \\
PM & 541 & 825 & 625 & 350 \\
below PM & 212 & 200 & 459 & 75 \\
\hline
\end{tabular}

Notes: $\mathrm{PM}=$ Pyroxenite Marker; $\mathrm{opx}=$ orthopyroxene 


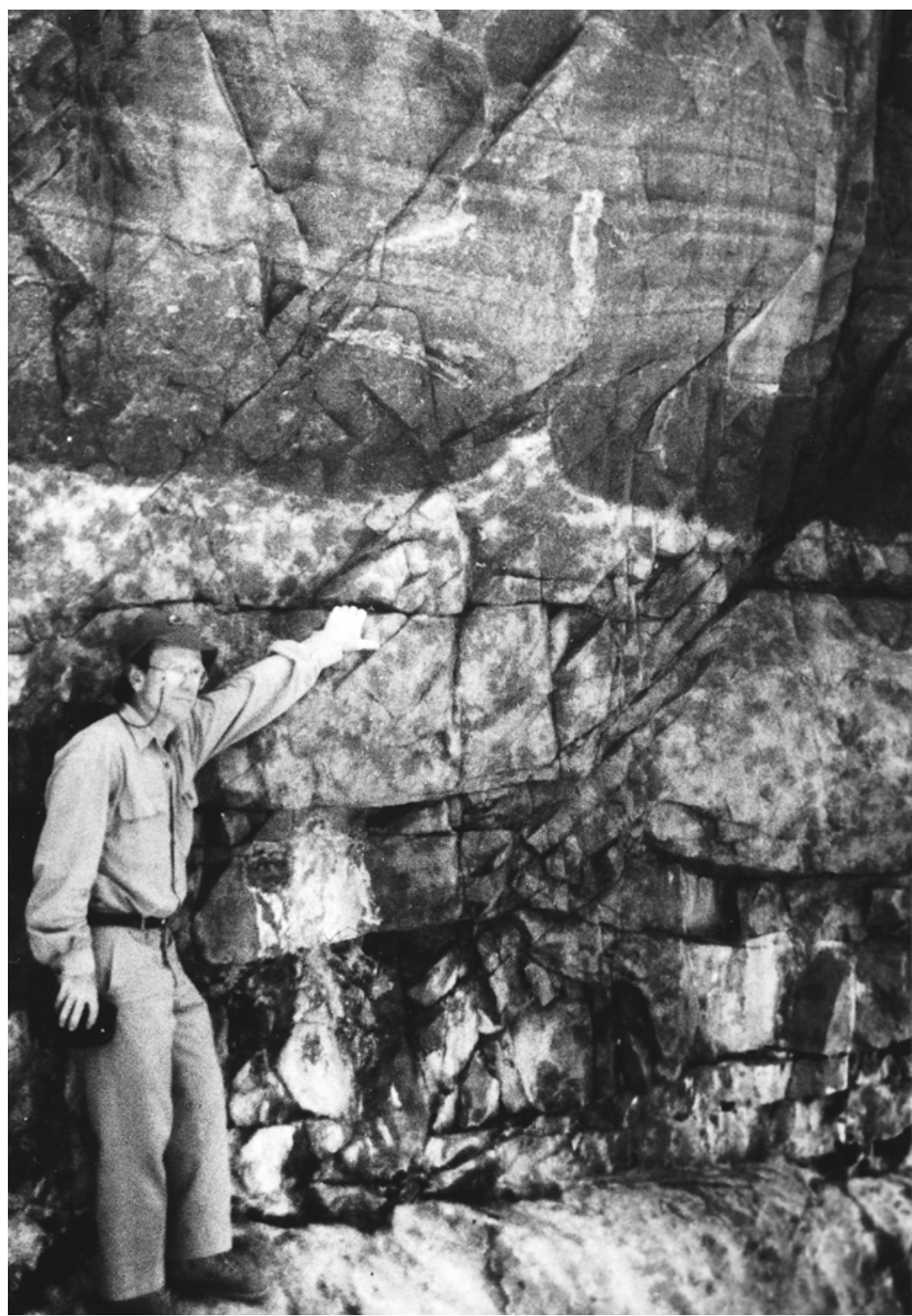

Figure 2. The Pyroxenite Marker as exposed on Mooimeisjesfontein. Note the lobate contact between the pyroxenite and the underlying mottled anorthosite, as well as the flame-like anorthosite veins extending from the cusps into the overlying pyroxenite.

reaction replacement phenomena (Nicholson and Mathez, 1991). Further, Parsons and Becker (1987) described load structures very similar in appearance to those described here from the Klokken intrusion of Greenland.

\section{Sample description}

Samples of the Pyroxenite Marker were obtained from 6 localities in the western, eastern and northern lobes of the Bushveld Complex (Figure 1). Sample 1 (Table 2) was obtained from borehole BK2 in the Bierkraal area near Rustenburg, within the basal $10 \mathrm{~cm}$ of the Pyroxenite Marker. At this locality, the layer is hosted by gabbronorites (see Kruger et al., 1987; Cawthorn et al., 1991, for a description of the core). Sample 2 was obtained from the base of the Pyroxenite Marker in borehole VB1 at Northam platinum mine in the western Bushveld Complex. Five additional borehole samples from Northam mine (samples 9 to 13) are from the gabbronoritic hanging- and footwall of the layer. The eastern Bushveld Complex is represented by 4 surface samples from 3 different localities. Samples 3 and 4 were collected on the farm Mooimeisjesfontein, with sample 3 derived from the cliff shown in Figure 2, some $5 \mathrm{~cm}$ above the base of the layer, which is approximately $40 \mathrm{~cm}$ in width at this locality. Sample 4 was collected from poorly exposed Pyroxenite Marker, on a hill slope some 100 to $200 \mathrm{~m}$ to the north-east of the cliff. The Pyroxenite Marker at Mooimeisjesfontein is underlain by mottled anorthosite, but the hanging wall is gabbronorite. The remaining two samples (5 and 6) are from the farms Mapochsgronde (next to the Roossenekal-Lydenburg road at $\mathrm{km}$ stone 58.0) and Thornhill. For both samples their precise stratigraphic position within the layer, as well as the thickness of the layer is not known. Samples 7 and 8 are also surface samples that were collected on the farm Vriesland in the northern lobe. They represent 2 layers of melanoritic 
Table 2. Selected element concentrations in samples from the Pyroxenite Marker and its adjacent hostrocks

\begin{tabular}{|c|c|c|c|c|c|c|c|c|c|c|c|c|c|c|}
\hline \multicolumn{6}{|c|}{ Pyroxenite Marker } & \multicolumn{9}{|c|}{ Host rocks } \\
\hline \multirow{2}{*}{\multicolumn{2}{|c|}{$\begin{array}{l}\text { Sample } \\
\text { Locality }\end{array}$}} & \multirow{3}{*}{$\begin{array}{r}\mathbf{1} \\
\text { Bierkr } \\
793\end{array}$} & \multirow{3}{*}{$\begin{array}{r}2 \\
\text { Northam } \\
\text { VB1 1223 } \\
\text { na }\end{array}$} & \multirow{3}{*}{$\begin{array}{r}3 \\
\text { Mooi } \\
139\end{array}$} & \multirow{3}{*}{$\begin{array}{r}\mathbf{4} \\
\text { Mooi } \\
411 \\
\end{array}$} & \multirow{3}{*}{$\begin{array}{r}\mathbf{5} \\
\text { Mapoch } \\
640\end{array}$} & \multirow{3}{*}{$\begin{array}{r}\mathbf{6} \\
\text { Thornh } \\
974\end{array}$} & \multirow{3}{*}{$\begin{array}{r}\begin{array}{r}7 \\
\text { Vries1 } \\
\text { upp.layer }\end{array} \\
\text { na }\end{array}$} & \multirow{3}{*}{ 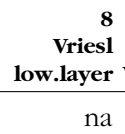 } & \multirow{2}{*}{$\begin{array}{r}9 \\
\text { Northam } \\
\text { VB1 } 1214\end{array}$} & \multirow{3}{*}{ 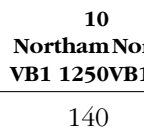 } & \multirow{2}{*}{$\begin{array}{r}11 \\
\text { ortham } \\
311268\end{array}$} & \multirow{2}{*}{$\begin{array}{r}12 \\
\text { Northam } \\
\text { RY5 1473 } \\
\end{array}$} & \multirow{2}{*}{$\begin{array}{r}13 \\
\text { Northam } \\
\text { RY5 1511 } \\
\end{array}$} \\
\hline & & & & & & & & & & & & & & \\
\hline $\mathrm{Cr}$ & (ppm) & & & & & & & & & na & & 41 & 192 & 24 \\
\hline $\mathrm{Ni}$ & $"$ & 410 & 194 & 170 & 270 & 552 & 480 & 147 & 133 & na & 95 & 142 & 104 & 79 \\
\hline $\mathrm{Cu}$ & $"$ & 4 & 42 & 15 & 14 & 123 & 100 & 59 & 22 & 16 & 26 & 17 & 27 & 25 \\
\hline $\mathrm{S}$ & $"$ & na & 430 & 113 & 150 & 1963 & 100 & $<50$ & $<50$ & 870 & 63 & $<20$ & 85 & 80 \\
\hline $\mathrm{La}$ & $"$ & 2.41 & na & na & 2.06 & 1.35 & 1.16 & 0.77 & 0.82 & na & 1.65 & 0.9 & 10.8 & 6.1 \\
\hline $\mathrm{Ce}$ & $"$ & 4.9 & na & na & 4.2 & 2.54 & 2.7 & 1.5 & 1.3 & na & 3.24 & 1.6 & 22.7 & 11.4 \\
\hline $\mathrm{Nd}$ & $"$ & 3.3 & na & na & 1.3 & 1.44 & 1.5 & $<0.64$ & 1.1 & na & 1.1 & 1.7 & 7.87 & 4.3 \\
\hline $\mathrm{Sm}$ & $"$ & 1.21 & na & na & 0.62 & 0.53 & 0.64 & 0.19 & 0.17 & na & 0.41 & 0.35 & 1.58 & 1.17 \\
\hline $\mathrm{Eu}$ & $"$ & 0.15 & na & na & 0.31 & 0.15 & 0.06 & 0.38 & 0.26 & na & 0.5 & 0.3 & 0.7 & 0.65 \\
\hline $\mathrm{Tb}$ & $"$ & 0.26 & na & na & 0.15 & 0.11 & 0.12 & 0.08 & 0.07 & na & 0.1 & $<0.2$ & 0.2 & 0.2 \\
\hline $\mathrm{Yb}$ & $"$ & 1.34 & na & na & 0.76 & 0.72 & 0.81 & 0.48 & 0.41 & na & 0.47 & 0.36 & 0.74 & 0.71 \\
\hline $\mathrm{Lu}$ & $"$ & 0.22 & na & na & 0.12 & 0.13 & 0.14 & 0.08 & 0.072 & na & 0.08 & 0.07 & 0.17 & 0.14 \\
\hline Th & $"$ & 0.17 & na & na & 0.31 & 0.24 & 0.05 & $<0.04$ & $<0.05$ & na & $<0.2$ & $<0.2$ & 2.1 & 1.4 \\
\hline $\mathrm{Hf}$ & $"$ & 0.32 & na & na & 0.34 & 0.23 & 0.25 & $<0.12$ & 0.13 & na & $<0.3$ & $<0.3$ & 1.3 & 0.65 \\
\hline Os & (ppb) & 0.5 & $<0.7$ & $<0.2$ & $<0.4$ & 0.2 & $<0.3$ & $<0.3$ & $<0.5$ & $<0.7$ & $<1.0$ & $<1.2$ & 0.8 & $<1.0$ \\
\hline Ir & $"$ & 1.27 & 0.87 & 0.05 & 0.20 & 0.87 & 0.18 & 0.04 & 0.02 & 0.07 & 0.07 & 0.09 & 0.07 & 0.14 \\
\hline $\mathrm{Ru}$ & $"$ & 2 & 2 & 3 & 2 & 4 & 1 & $<2$ & $<3$ & $<2.3$ & $<2$ & 2 & 2 & $<5$ \\
\hline $\mathrm{Rh}$ & $"$ & 4.0 & 0.2 & 0.1 & 0.5 & 4.7 & 0.9 & 0.4 & $<0.3$ & 0.3 & $<0.2$ & 0.2 & 0.54 & 0.36 \\
\hline $\mathrm{Pt}$ & " & 82 & $<3$ & 2 & 9 & 8 & 15 & $<2$ & $<1$ & $<3$ & $<4$ & 8 & $<4$ & 19 \\
\hline $\mathrm{Pd}$ & $"$ & 21 & $<4$ & $<1$ & 2 & 15 & 15 & $<4$ & $<2$ & $<3$ & 2 & 1 & 6 & $<6$ \\
\hline $\mathrm{Au}$ & $"$ & 2.4 & 0.8 & 0.7 & 0.3 & 4.3 & 1.2 & 0.6 & 0.5 & 0.5 & 0.2 & 0.8 & 0.2 & 0.2 \\
\hline
\end{tabular}

Notes: Mooi $=$ Mooimeisjesfontein; Map $=$ Mapochsgronde; Bierkr $=$ Bierkraal; Thornh $=$ Thornhill, Vries $=$ Vriesland; na: not analysed

Pyroxenite Marker, each being approximately $1 \mathrm{~m}$ thick and separated from each other by some $2 \mathrm{~m}$ of anorthosite. Both the foot- and hanging wall of this doublet also consist of anorthosite.

Based on petrographic observations and the concentration of highly incompatible trace elements to be discussed below, the Pyroxenite Marker is an orthopyroxene meso- to orthocumulate at Mapochsgronde, Thornhill, Bierkraal and in sample 4 from Mooimeisjesfontein, containing subhedral and anhedral orthopyroxene (70 to 90 volume \%), anhedral interstitial plagioclase (10 to 20 volume $\%$ ) and clinopyroxene (5 to 15 volume \%). Sample 3 from Mooimeisjesfontein is a melanorite and has between 20 and 40\% subhedral and anhedral plagioclase, 10\% clinopyroxene, and 40 to 60\% large anhedral poikilitic orthopyroxene, giving the rock a sub-ophitic texture. The sample from Northam is a clinopyroxenite, with $83 \%$ clinopyroxene, $1.7 \%$ plagioclase, $14.8 \%$ orthopyroxene and $0.5 \%$ opaques. The two samples from Vriesland are norites with a similar texture to sample 3 from Mooimeisjesfontein and approximately even proportions of large (up to $1 \mathrm{~cm})$ poikilitic orthopyroxene and finer grained (up to $1 \mathrm{~mm}$ ) plagioclase partly included in the orthopyroxene.

Biotite is generally rare, but secondary magnetite is present in serpentinized zones of alteration within orthopyroxene. The sample from Mapochsgronde contains in excess of $0.5 \%$ sulphides (pyrrhotite, with lesser chalcopyrite and pyrite), but in the other samples no visible sulphides are present. Mineral compositions of the samples have not yet been determined by us, but summarized data of Marais (1977) from some localities in the eastern Bushveld Complex are given in Table 1.

\section{Analytical results}

Concentrations of the platinum-group elements, $\mathrm{Au}, \mathrm{Cu}$, $\mathrm{Ni}, \mathrm{S}$, and a number of other elements in the analysed samples are listed in Table 2 . In the case of sample 1, insufficient sample material was available to perform a $\mathrm{S}$ analysis. However, no sulphides were visible in hand specimen. The PGE were determined by instrumental neutron activation (INAA) at the University of Quebec at Chicoutimi (UQAC) after collection of the metals in a Nisulphide bead. The analytical procedures and conditions are summarized in Maier and Barnes (1999). Cu was determined by atomic absorption at UQAC, Ni by XRF at the University of Pretoria, and S by LECO titration, at UQAC. The other elements listed were determined by INAA on $2 \mathrm{~g}$ of whole-rock powder (see Bédard and Barnes, 1990, for analytical methods and conditions), at UQAC.

Chondrite-normalized REE patterns for four samples of the Pyroxenite Marker are flat and have pronounced negative $\mathrm{Eu}$ anomalies (Figure $3 \mathrm{~b}$ ), indicative of crystallization from magma that was fractionating plagioclase. This is in marked contrast to the patterns for the over- and underlying rocks, which have positive Eu anomalies and fractionated REE patterns (Figures. 3a; c; Cawthorn et al., 1991; Maier and Barnes, 1998). Concentrations of the highly incompatible elements Th, Hf and Sm indicate that the Pyroxenite Marker contains approximately 10 to $20 \%$ trapped melt, depending on whether B1 or B3 magmas are chosen as parents (unpublished data of E. Curl). Trapped melt contents in the gabbroic host rocks appear to be highly variable, based on the variation in REE contents observed at Northam (Figure 3d).

$\mathrm{S}$ contents of the Pyroxenite Marker vary between less than 50 and 1960ppm. The analysed host rock 


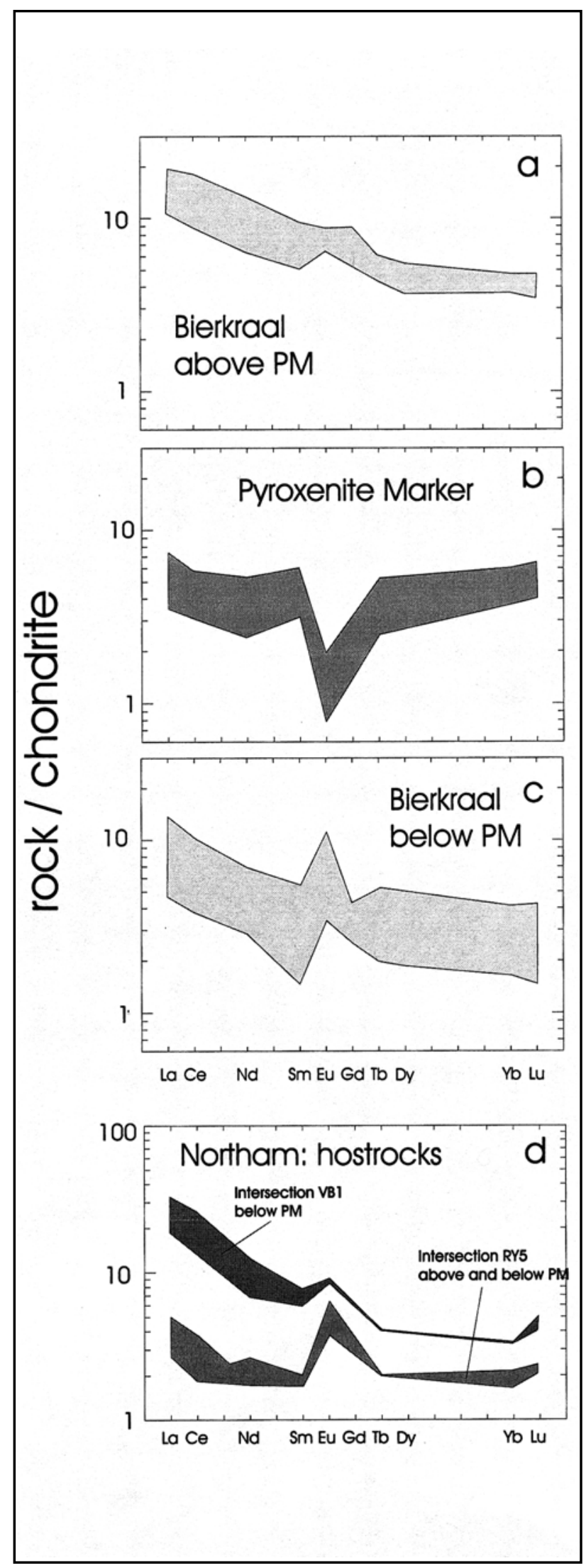

Figure 3. Average chondrite-normalized REE patterns of (a) the over- and (c) the underlying gabbroic rocks to the Pyroxenite Marker at Bierkraal (from Cawthorn et al., 1991), (b) four samples of the Pyroxenite Marker analysed in this study, and (d) the host rocks to the Pyroxenite Marker at Northam. Normalization factors are from Nakamura (1974). gabbros have somewhat lower average $\mathrm{S}$ contents, generally below 100ppm (Table 2, and Maier and Barnes, 1998).

$\mathrm{Cu}$ contents vary between 4 and $123 \mathrm{ppm}$, with the latter value coming from the S-enriched sample at Mapochsgronde. Three of the samples fall within the background values for the upper Main Zone of between 10 and 30ppm Cu (Table 2, and Maier and Barnes, 1999). The sample from Bierkraal is extremely Cu-poor suggesting low sulphide contents, while the two samples from Mapochsgronde and Thornhill contain elevated $\mathrm{Cu}$ contents. In view of the chalcophile nature of $\mathrm{Cu}$ (Dsulphide melt/silicate melt $=1000$, Francis, 1990), there is a remarkably poor correlation between $\mathrm{S}$ and $\mathrm{Cu}$ in our samples. Ni contents range between 130 and 480ppm. Orthopyroxene in the Pyroxenite Marker contains between 300 and 400ppm Ni (Marais, 1977), accounting for the bulk of the $\mathrm{Ni}$ in the rock, and this explains the observed lack of correlation between $\mathrm{S}$ and $\mathrm{Ni}$.

Five of the samples from the Pyroxenite Marker have low PGE contents similar to the average levels observed in the remainder of the Main Zone (Figure 4; Table 2; Maier and Barnes, 1999). They have noble metal patterns similar in shape to those from the remainder of the Main Zone (Maier and Barnes, 1998, and Figure 4), with a steady increase from Ir to Pd and a flattening out from $\mathrm{Pd}$ to $\mathrm{Au}$. Cu and Ni occur mostly at higher mantlenormalized levels than the PGE (Cu/Pdmantle significantly higher than unity, $\mathrm{Ni} / \mathrm{Ir}_{\text {mantle }} 1.26$ ). In the three remaining samples, the PGE contents are somewhat elevated, reaching $110 \mathrm{ppb}$ in the sample from Bierkraal. This sample, in particular, shows the arch-shaped pattern typical of PGE-enriched cumulates in the Upper Critical Zone, with low $\mathrm{Ni} / \mathrm{Ir}$ mantle and $\mathrm{Cu} / \mathrm{Pd}$ mantle ratios (Figure 4). The average Pt/Pd ratio of the samples is 2.2, somewhat higher than that of most of the remainder of the Main Zone, but within the range of the uppermost portion of the Critical Zone (Maier and Barnes, 1999). $\mathrm{Pd} / \mathrm{Ir}$ and $\mathrm{Pt}+\mathrm{Pd} / \mathrm{Os}+\mathrm{Ir}+\mathrm{Ru}$ ratios are too variable to allow meaningful comparisons with other portions of the Bushveld Complex.

\section{Discussion \\ Previous models for the origin of the Pyroxenite Marker}

Based on the compositional and mineralogical reversal observed at the level of the Pyroxenite Marker, as well as the more mafic nature of the layer relative to its host rocks, most authors argued that the chamber had been replenished by relatively undifferentiated magma at this level (von Gruenewaldt, 1973, Kruger et al., 1987; Cawthorn et al., 1991). The nature of the replenishing magma, however, has been poorly constrained. The most specific suggestions come from Davies and Cawthorn (1984) who proposed a magma slightly more differentiated than the B2 magma of Sharpe (1981), with lower $\mathrm{MgO}, \mathrm{Cr}$ and $\mathrm{Ni}$ contents, and represented by finegrained hypersthene gabbro sills in the Rustenburg area. Cawthorn et al. (1991) showed that this magma had 


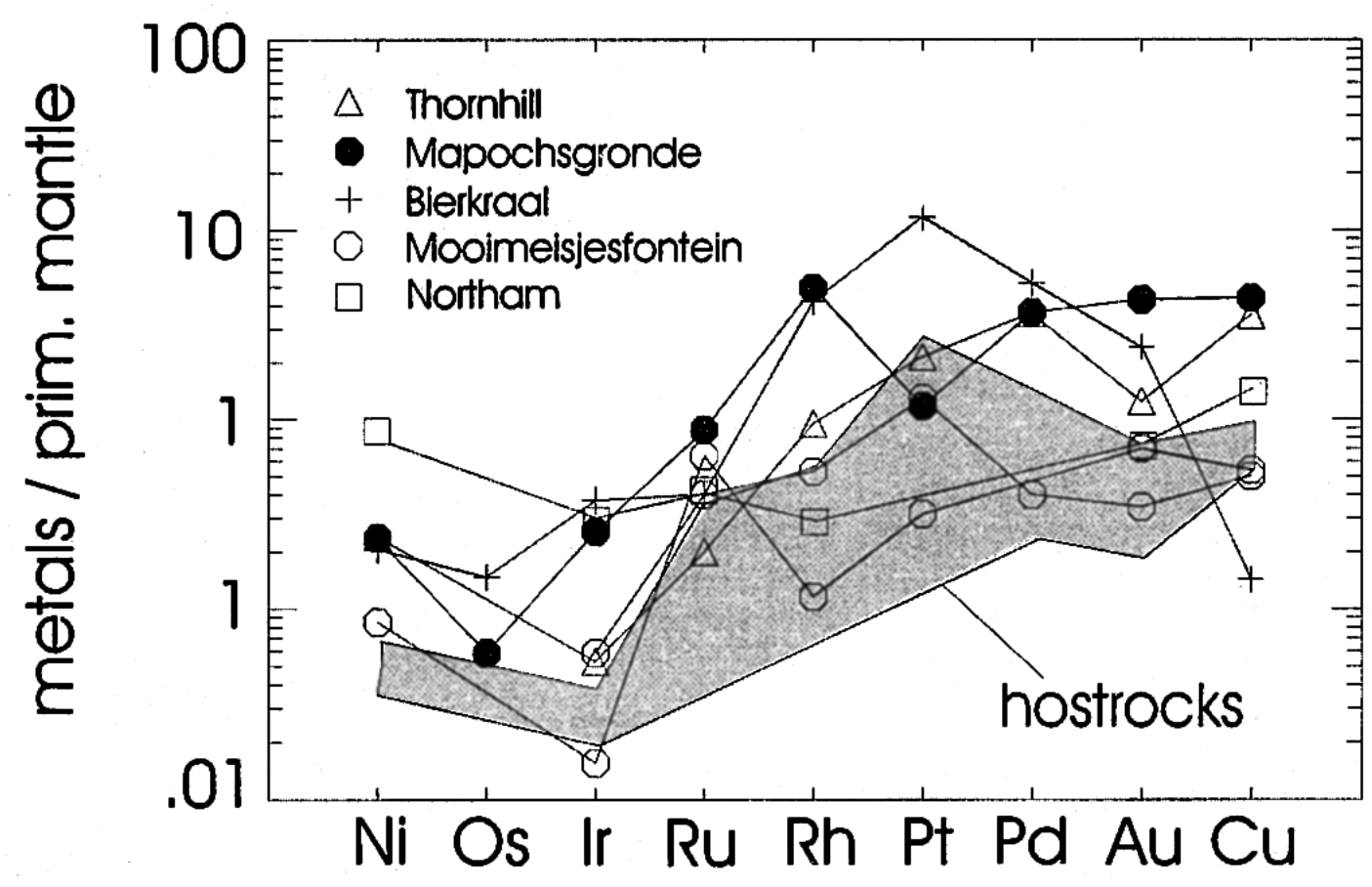

Figure 4. $\mathrm{Cu}$, Ni and PGE contents of the analysed rocks, normalized to primitive mantle (normalization factors are from Barnes and Maier, 1999).

elevated REE concentrations compared to the magma from which the underlying cumulates crystallized, and a negative Eu anomaly. This would seem to be in accord with the negative Eu anomalies observed in the four analysed samples of the Pyroxenite Marker, although these patterns may also be explained by mixing of a primitive replenishing magma with differentiated resident magma.

There have been two alternative models proposed for the origin of the Pyroxenite Marker. (i) Klemm et al. (1985), while accepting the concept of magma replenishment in the upper Main Zone, suggested that the Pyroxenite Marker itself formed due to the resulting increase in pressure in the chamber, enlarging the stability field of pyroxene. (ii) Based on Sr-isotopic data, Sharpe (1985) suggested that intrusion of relatively cool and dense Main Zone magma above the level of the Bastard Reef led to upward displacement of warmer and lighter, resident, Critical Zone magma. The model of Sharpe was discarded by several other workers (Kruger et al., 1987; Cawthorn et al., 1991; Eales and Cawthorn, 1996), based on compositional, thermal, and density considerations. Their main argument is that, due to heating from above, the cooler basal batch of Main Zone magma could not crystallize until mixing and homogenization of the two distinct magma batches occurred, and this would eliminate the phase and compositional layering so characteristic of the Pyroxenite Marker. Further, they argued that the Main Zone, if it crystallized as an essentially closed system, should contain more magnetite than the minor amounts observed, but Scoon and Mitchell (1994) showed that segregation of late-stage Fe-rich magma to form discordant iron-rich ultramafic pegmatites (IRUPs) in the Upper Critical, Main, and Upper Zones is a much more common phenomenon than previously thought. Perhaps more problematic is the question about how mixing between magmas that both had plagioclase on the liquidus would have driven the hybrid into the stability field of orthopyroxene alone to cause precipitation of the Pyroxenite Marker. Changes in pressure, as proposed by Klemm et al., (1985), or other intrinsic conditions would offer a possible solution, but remain to be supported independently.

\section{The Main Zone: intrusion of a plagioclase-rich crystal mush?}

Maier and Barnes (1998) showed that the average composition of the Main Zone cumulates (calculated from their REE data and the data of Mitchell, 1986) is remarkably similar to that of sills in the floor of the Main Zone thought to represent the parental magmas to the Main Zone. They therefore proposed that the Main Zone crystallized as a largely closed system. In that case, the poorly developed cryptic variation observed in large parts of the Main Zone (Mitchell, 1990) could be the result of limited crystal fractionation. Together with the distinct positive Eu anomalies but low incompatible trace element concentrations of the sills in the floor of the Main Zone relative to other high Al-tholeiitic basalts 
(Harmer and Sharpe, 1985), this raises the possibility that the Main Zone magma intruded as a plagioclase-rich crystal mush. It is interesting, in this regard, to note that many of the marginal rocks identified by Sharpe (1981) to be associated with the Main Zone appear to have a coarser grain size than the B1 and B2 groups. Other petrographical evidence in support of the model comprises intense deformation textures of feldspar in Main Zone gabbronorites in the northwestern Bushveld Complex (Eales, pers. com.), including common fracturing and breaking of grains, secondary twinning, and mortar textures. Further, the Nd isotopic data of Maier et al. (2000) indicate that the Main Zone magma contained up to $45 \%$ of a component of plagioclaseenriched residual crust. This would essentially demand bulk assimilation of the residual crust and would result in a magma containing a large proportion of partially or undissolved crustal material. If this model were correct, then the intruding Main Zone magma may have had an even lower temperature, and a higher density and viscosity than assumed by Sharpe (1985), lending support to his model. And finally, some workers (e.g. Czamanske and Bohlen, 1990) equally interpret thick anorthosite units in the Stillwater Complex as intrusions of crystal mushes.

We suggest that the intrusion of a relatively cold crystal mush led to supercooling at the base of the uplifted residual magma batch, possibly kinetic suppression of plagioclase crystallization within the latter, but continued growth of orthopyroxene, resulting in the development of ophitic textures in several of the investigated samples of the Pyroxenite Marker. Convective overturn and homogenization of the two distinct magma batches in the chamber would have been prevented by the high viscosity of the intruding crystal mush, but some resorption of plagioclase phenocrysts in the upper portions of the intruded mush layer may have occurred. The developing gravitational instability between a lower melt-rich felsic layer and an upper mafic-ultramafic layer could have caused the lobate interface and the filter pressing of anorthositic melt observed in Figure 2. Some residual magma may also have seeped down into the intruding crystal mush, explaining the diffuse nature of the compositional reversal described by von Gruenewaldt (1973) and Cawthorn et al. (1991).

\section{Evidence from sulphide and noble metal \\ contents}

With the exception of two samples, the sulphide contents of the Pyroxenite Marker are relatively low and in the range of the under- and overlying rocks. The modelling of Li et al. (2001, this volume) indicate that cumulates from residual sulphide saturated Bushveld magmas may have S contents in excess of 800ppm S. However, this does not rule out crystallization of the Pyroxenite Marker from residual Upper Critical Zone magma. Segregating sulphide melt may remain entrained in the magma, and sulphides in cumulate rocks may be partially resorbed by percolating intercumulus volatilerich melts (Boudreau and McCallum, 1992).

PGE concentrations and patterns of the Pyroxenite Marker are highly variable, preventing meaningful comparisons of parameters such as $\mathrm{Pd} / \mathrm{Ir}$ and $\mathrm{Pt}+\mathrm{Pd} / \mathrm{Os}+\mathrm{Ir}+\mathrm{Ru}$ ratios with cumulates of the Main and Upper Critical Zones. However, The Pt/Pd ratios are less variable and suggest an Upper Critical Zone lineage. $\mathrm{Cu} / \mathrm{Pd}$ ratios are mainly above mantle values ( $c a$. 6500, Barnes and Maier, 1999) and argue against the replenishment of the chamber by a B1 or B2 Bushveld magma. Instead, such ratios are in accord with crystallization from metal depleted residual magmas.

\section{Implications for exploration}

The combined data presented here and in Harney et al. (1990) suggest that the potential of the Pyroxenite Marker as an ore deposit, raised by Wilhelm et al. (1997), is exceedingly low. The PGE and sulphide contents of our samples are, however, relatively variable, in accord with the general lithological heterogeneity of the Pyroxenite Marker. This raises the possibility that the layer may locally contain elevated sulphide and PGE contents, but based on the petrogenetic model envisaged by us for the origin of the layer, such occurrences are likely to be sporadic.

\section{Acknowledgements}

This project was supported by a research development grant (to WDM) by the University of Pretoria and an NSERC grant (to SJB). We thank R.G. Cawthorn for providing the samples from Bierkraal and Thornhill. D.L. Reid and C.J. Hatton are thanked for their critical reviews.

\section{References}

Andersen, J.C.O., Rasmussen, H., Nielsen, T.F.D. and Ronsbo, J.G. (1998). The triple group and the Platinova gold and palladium reefs in the Skeargaard Intrusion. Stratigraphic and petrographic relationships. Economic Geology, 93, 488-509.

Barnes, S.-J. and Maier, W.D. (1999). The fractionation of $\mathrm{Ni}, \mathrm{Cu}$ and the noble metals in silicate and sulphide liquids. In: Keays, R.R., Lesher, C.M., Lightfoot, P.C. and Farrow, C.E.G. (Eds.), Dynamic processes in magmatic ore deposits and their application to mineral exploration. Geological Association of Canada, Short Course Notes, 13, 69-106.

Bédard, L.P. and Barnes, S.-J. (1990). Instrumental neutron activation analysis by collecting only one spectrum: results for international geochemical reference standards. Geostandards Newsletter, 14, 479-484.

Boudreau, A.E. and McCallum, I.S. (1992). Concentrations of platinum-group elements by magmatic fluids in layered intrusions. Economic Geology, 87, 1830-1848.

Cawthorn, R.G., Meyer, P.S. and Kruger, F.J. (1991). Major addition of magma at the Pyroxenite Marker in the Western Bushveld Complex, South Africa. Journal of Petrology, 32, 739-763.

Czamanske, G.K. and Bohlen, S.R. (1990). The Stillwater Complex and its anorthosites: an accident of magmatic underplating. American Mineralogist, 75, 37-45.

Davies, G. and Cawthorn, R.G. (1984). Mineralogical data on a multiple intrusion in the Rustenburg Layered Suite of the Bushveld Complex. Mineralogical Magazine, 48, 469-480.

Eales, H.V. and Cawthorn, R.G. (1996). The Bushveld Complex. In: Cawthorn, R.G. (Ed.), Layered Intrusions, Elsevier, Amsterdam, Netherlands, 181-229. 
Eales, H.V., Field, M., De Klerk, W.J. and Scoon, R.N. (1988). Regional trends of chemical variation and thermal erosion in the Upper Critical Zone, Western Bushveld Complex. Mineralogical Magazine, 52, 63-79.

Francis, R.D. (1990). Sulfide globules in mid-ocean ridge basalts (MORB), and the effect of oxygen abundance in Fe-S-O liquids on the ability of those liquids to partition metals from MORB and komatiite magmas. Chemical Geology, 85, 199-213.

Harmer, R.E. and Sharpe, M.R. (1985). Field relations and strontium isotope systematics of the marginal rocks of the eastern Bushveld Complex. Economic Geology, 80, 813-837.

Harney, D.M.W., Merkle, R.K.W. and Von Gruenewaldt, G. (1990). Platinumgroup element behaviour in the lower part of the Upper Zone, eastern Bushveld Complex - implications for the formation of the Main Magnetite Layer. Economic Geology, 85, 1777-1789.

Klemm, D.D., Ketterer, S., Reichhardt, F., Steindl, J. and Weber-Diefenbach, K. (1985). Implication of vertical and lateral compositional variations across the Pyroxenite Marker and its associated rocks in the upper part of the Main Zone in the Eastern Bushveld Complex: Economic Geology, 80, 1007-1015.

Kruger, F.J. (1994). The Sr-isotopic stratigraphy of the Western Bushveld Complex. South African Journal of Geology, 97, 393-398.

Kruger, F.J., Cawthorn, R.G. and Walsh, K.L. (1987). Strontium isotopic evidence against magma addition in the Upper Zone of the Bushveld Complex: Earth and Planetary Science Letters, 84, 51-58.

Lee, C.A. (1981). Post-depositional structures in the Bushveld Complex mafic sequence. Journal of the Geological Society of London, 138, 327-341.

Li, C, Maier, W.D., and De Waal, S.A. (2001) Magmatic Ni-Cu versus PGE deposits: contrasting genetic controls and exploration implications. South African Journal of Geology, 104, 309-318

Maier, W.D. and Barnes, S.-J. (1998). Concentrations of rare earth elements in silicate rocks of the Lower, Critical and Main Zones of the Bushveld Complex. Chemical Geology, 150, 85-103.

Maier, W.D., and Barnes, S.-J. (1999). Platinum-group elements in silicate rocks of the Lower, Critical and Main Zones at Union Section, Western Bushveld Complex. Journal of Petrology, 40, 1647-1671.

Maier, W.D., Arndt, N.T., Curl, E. (2000). Progressive crustal contamination of the Bushveld Complex: Evidence from Nd isotopic analyses of the cumulate rocks. Contributions to Mineralogy and Petrology, 140, 316-327.

Marais, C.L. (1977). An investigation of the Pyroxenite Marker and the associated rocks in the Main Zone of the Eastern Bushveld Complex. Unpublished M.Sc. dissertation, Pretoria, University of Pretoria, South
Africa, $87 \mathrm{p}$.

Mitchell, A.A. (1990). The stratigraphy, petrography and mineralogy of the Main Zone of the Northwestern Bushveld Complex. South African Journal of Geology, 93, 818-831.

Molyneux, T.G. (1974). A geological investigation of the Bushveld Complex in Sekhukhuneland and part of the Steelpoort valley. Transactions of the Geological Society of South Africa, 77, 329-338.

Nakamura, N. (1974). Determination of REE, Ba, Fe, Mg, Na and K in carbonaceous and ordinary chondrites. Geochimica et Cosmochimica Acta, 38, $757-773$.

Naldrett, A.J. and von Gruenewaldt, G. (1989). Association of platinum-group elements with chromitite in layered intrusions and ophiolite complexes. Economic Geology, 84, 180-187.

Nicholson, D.M. and Mathez, E.A. (1991). Petrogenesis of the Merensky Reef in the Rustenburg section of the Bushveld Complex. Contributions to Mineralogy and Petrology, 107, 293-309.

Parsons, I. and Becker, S.M. (1987). Layering, compaction and post-magmatic processes in the Klokken intrusion. In: Parsons, I. (Editor), Origins of Igneous Layering, NATO ASI Series, D. Reidel, Dordrecht, 21-92.

Prendergast, M., D. (2000). Layering and precious metals mineralization in the Rincon del Tigre Complex, eastern Bolivia. Economic Geology, 95, 113-130

Scoon, R.N. and Mitchell, A.A. (1994). Discordant iron-rich ultramafic pegmatites in the Bushveld Complex and their relationship to iron-rich intercumulus and residual liquids. Journal of Petrology, 35, 881-917.

Sharpe, M.R. (1981). The chronology of magma influxes to the eastern compartment of the Bushveld Complex as exemplified by its marginal border groups: Journal of the Geological Society of London, 138, 307-326.

Sharpe, M.R. (1985). Strontium isotope evidence for preserved density stratification in the Main Zone of the Bushveld Complex: Nature, 316, 119-126.

Von Gruenewaldt, G. (1973). The Main and Upper Zones of the Bushveld Complex in the Roossenekal area, eastern Transvaal. Transactions of the Geological Society of South Africa, 76, 207-227.

Wilhelm, H.J., Zhang, H., Chen, F.L., Elsenbroek, J.H., Lombard, M. and de Bruin, D. (1997). Geochemical exploration for platinum-group elements in the Bushveld Complex, South Africa: Mineralium Deposita, 32, 349-361.

Editorial Handling: J. M. Barton Jr. 